\title{
AN INVESTIGATION TOWARDS DEVELOPING A MOLECULAR APPROACH TO IMPROVE THE EFFICIENCY OF COCONUT BREEDING BY RAPD-MARKER ASSISTED SELECTION
}

\author{
By
}

\author{
J.M.D.T. Everard
}

\begin{abstract}
Tall, dwarf green and San Ramon are three phenotypically distinct forms of coconut, currently used for production of hybrid seeds in Sri Lanka. Development of molecular markers for further improvement of important economic traits of these hybrids was thought important due to various constraints faced by conventional breeders. Sixty random primers (OPERON) were used for generation of RAPD profiles using DNA from 3 individuals of each form. All the sixty primers except one (OPC3) yielded RAPD-PCR products with coconut DNA. They generated a total of 326 consistently amplified bands of which 54 distinguished tall, dwarf green and San Ramon. Among RAPDs detected 16 and 8 were specific to tall and dwarf respectively, 18 distinguished dwarf and San Ramon from tall, 9 distinguished tall and San Ramon from dwarf and 3 distinguished tall and dwarf green from San Ramon. It is expected to study the segregation of these markers in F2 populations derived from tall $\mathrm{x}$ dwarf green and tall $\mathrm{x}$ San Ramon F1 palms.
\end{abstract}

\section{INTRODUCTION}

The genetic improvement of coconut by conventional methods has never reached the incomparable breeding achievements of rice, maize or wheat mainly due to constraints common to all perennial crops such as long juvenile phase and time and cost limitations, Coconut was further disadvantageous due to lack of a viable mechanism for vegetative propagation and the inherent heterozygosity associated with the commercially grown 'tall' coconut type, typica typica, (Liyanage, 1958)

Identification of genetically diverse parents for obtaining maximum heterosis is impracticable by screening coconut genotypes by morphological differences alone since in typica typica each individual is a unique heterozygous genotype and the phenotypic expression of most morphological traits is highly environmental-prone and often masks the true genetic variation. Therefore, it is advantageous to develop more direct biochemical methods to couple with the selection criteria used for determining parents for crosses aimed at improving important economic traits.

Molecular marker technology has gained immense popularity ever since the development of first DNA marker, Restriction Fragment Length Polymorphisms or RFLP (Botstein, et al., 1980) and recognition of its utility by Beckmann and Soller (1993) for plant genome analysis. Advent of the polymerase chain reaction (PCR) by Mullis et al., (1986) resulted in development of a substantial array of marker-systems, such as Random Amplified Polymorphic DNA or RAPD (Williams, 1991), Simple Sequence Repeat Polymorphism or SSRP (Serikawa, et al., 1992) and Amplified Fragment Length Polymorphisms or AFLP (Zabeau and Voss, 1993) for plant genome analysis.

RAPDs, being disadvantages by its dominant pattern of segregation and relatively poor reproducibility, it is the choice of many for studying 'new genomes' since other techniques require

\footnotetext{
${ }^{1}$ Coconut Research Institute, Lunuwila, Sri Lanka
} 
either previously cloned DNA fragments or DNA sequence information of the target genome or use of isotopes. In the past RAPD technique was rather prone to problems due to a lack of reproducibility of banding patterns between and within laboratories. To a great extent these problems have now been reduced by adherence to use of ultra purified and accurately quantified PCR reagents and protocols needed for reproducible results.

Coconut was not much benefited previously by DNA technology apart from a few studies. First published work was a less successful attempt made by Rhode et al., (1992) for detection of RFLPs by probing a repetitive EcoRI fragment of the coconut DNA which was characterized in the same study as a homology of a transposable element present in Copia and some other species. Subsequently, this information was utilized to develop a new system of markers called inverse sequence tagged repeats (ISTR) for characterization of coconut germplasm. Everard (1996a) constructed a library of coconut DNA by sub cloning Sau3AI fragments and had a meager success in detection of RFLPs on Southern blots of EcoRI, EcoRV and DraI digested fragments of tall and dwarf coconut DNA.

Everard et al., (1996b) had better success with detection of polymorphisms among tall and dwarf coconut with RAPDs. They have detected 18 polymorphisms using 38 randomly generated 10 -mer primers in RAPD-PCR. These primers segregated in a family of $18 \mathrm{~F} 2$ individuals in the Mendellian fashion assuring the potential of RAPDs for detection of genetic markers among major coconut varieties. Everard et al., (1998) also demonstrated the ease of developing RAPD profiles for characterization of coconut germplasm.

In view of developing molecular markers to assist coconut breeding, detection of polymorphisms among coconut forms was considered as a priority. This paper describes early results of a long-term study aimed at detection of variety specific DNA polymorphisms among tall, dwarf green and San Ramon, the three varieties of coconut currently used in Sri Lanka for production of hybrid seeds for use in marker assisted selection after tagging to important traits.

\section{MATERIALS AND METHODS}

Morphological description of the three coconut types, tall, dwarf green and San Ramon assayed is given in Table 1. Tender coconut leaves from three individuals each of these coconut varieties were used for isolation of DNA. Several methods have been used successfully for isolation of DNA from tender coconut leaves. Everard (1996) used a slightly modified mini prep protocol of Dellaporta et al., (1983). Rhode et al., (1995) and Ashburner et al., (1997) used modifications of Murray and Thompson's (1980) CTAB method by Doyle and Doyle's (1990) and Roggers and Bendich's (1985) respectively. In the current study the method derived by Wiesing and Karl (1997) form Doyle and Doyle's (1990) was used for isolation of DNA from tender coconut leaves.

Table 1. Taxonomy, distinctive morphological and reproductive features and distribution of the 3 coconut varieties used for detection of RAPDs.

\begin{tabular}{|l|l|l|l|}
\hline \multicolumn{1}{|c|}{ Accession } & \multicolumn{1}{|c|}{ Taxonomy } & \multicolumn{1}{|c|}{ Specific morphological and reproductive features } & \multicolumn{1}{c|}{ Source or origin } \\
\hline Tall (TT) & $\begin{array}{l}\text { var. Typica form } \\
\text { Typica (tall) }\end{array}$ & $\begin{array}{l}\text { Tall stature, allogamous, heterogeneous, bear in } 6 \\
-7 \text { years, medium sized nuts, 60 - 80 nuts per palm } \\
\text { per year }\end{array}$ & Common Tall \\
\hline San Ramon (SR) & $\begin{array}{l}\text { var. Typica form } \\
\text { San Ramon } \\
\text { (tall) }\end{array}$ & $\begin{array}{l}\text { Tall stature, allogamous, heterogeneous, bear in 6 } \\
-7 \text { years, medium - large sized nuts, round shaped } \\
\text { nuts, high copra content, about than 60 - 80 nuts } \\
\text { per palm per year }\end{array}$ & Philippines \\
\hline Dwarf green (DG) & $\begin{array}{l}\text { var. Nana form } \\
\text { green dwarf }\end{array}$ & $\begin{array}{l}\text { Dwarf stature, autogamous, homogeneous, bear in } \\
3-4 \text { years, small sized green coloured nuts, low } \\
\text { copra content, 80 - 120 nuts per palm per year }\end{array}$ & Common green dwarf \\
\hline
\end{tabular}




\section{Procedure:}

Young coconut leaves, harvested a day prior to extraction were washed in distilled water, wiped, deribbed and cut into small pieces. Approximately $3 \mathrm{~g}$ were ground with mortar and pestle to a fine powder in the presence of liquid nitrogen. The powder was dispersed in $15 \mathrm{ml}$ of pre-warmed $\left(60{ }^{\circ} \mathrm{C}\right.$ ) isolation buffer [2\% CTAB (Sigma H6269), 1.4M NaCl, $20 \mathrm{Mm}$ EDTA (pH 8.0), $100 \mathrm{mM}$ Tris- $\mathrm{HCl}(\mathrm{pH} 8.0)$ and $0.2 \%$ b-mercaptoethanol added just prior to dispersing the sample] in a capped polypropylene tube and incubated for 60 minutes at $60{ }^{\circ} \mathrm{C}$.

The incubated suspension was extracted with $15 \mathrm{ml}$ of chloroform: isoamyl alcohol (24:1) by mixing gently (inverting and back) for 10 minutes and centrifuged in Beckmann (J2-21), J17 rotor for 10 minutes and $6,000 \mathrm{rpm}(5,000 \mathrm{~g})$ at room temperature $\left(30{ }^{\circ} \mathrm{C}\right)$. The aqueous phase was re-extracted with fresh chloroform-isoamyl alcohol and added RNAse A [50 mg/ml RNAse A (Sigma R6513) in $10 \mathrm{mM}$ Tris- $\mathrm{HCl}(\mathrm{pH} 7.5)$ and $15 \mathrm{mM} \mathrm{NaCl})]$ to a final concentration of 100 $\mathrm{mg} / \mathrm{ml}$, and incubated at $37{ }^{\circ} \mathrm{C}$ for 30 minutes.

Cold isopropanol ( 0.6 volumes) was added to the RNAse A treated mixture and kept for 5 minutes at room temperature. DNA, appeared as a white fibrous tangle, was picked up with the aid of a bent Pasteur pipette and washed in $20 \mathrm{ml}$ of washing solution $(76 \%$ ethanol and $10 \mathrm{mM}$ ammonium acetate) by gently agitating for about 20 minutes before spinning for $10 \mathrm{~min}$. and 6000 $\mathrm{rpm}(5000 \mathrm{~g})$ at $4{ }^{\circ} \mathrm{C}$. Drained the supernatant and pellet was allowed to suspend in $2 \mathrm{ml}$ of TE buffer [10 mM Tris-HCl (pH 8.0), 1 mM EDTA (pH 8.0)] overnight without agitation at $4{ }^{0} \mathrm{C}$.

The DNA suspension was treated with $1 \mathrm{ml}$ (0.5 volumes) of $7.5 \mathrm{M}$ Ammonium acetate, chilled on ice for 15 minutes and centrifuged for $30 \mathrm{~min}$. and $11,000 \mathrm{rpm}(10,000 \mathrm{~g})$ at $4{ }^{0} \mathrm{C}$. Transferred the supernatant to a new tube, 2 volumes of $96 \%$ ethanol was added and kept at $-20{ }^{\circ} \mathrm{C}$ for 60 minutes. The white fibrous tangle was picked up by a bent Pasteur pipette and washed on to a $1.5 \mathrm{ml}$ eppendorf with $1 \mathrm{ml}$ of $70 \%$ ethanol. Centrifuged in a microfuge for $10 \mathrm{~min}$. and top speed $(13,500 \mathrm{rpm})$. The final pellet was suspended in $500 \mathrm{ml}$ of TE. The purity and quantity of the DNA were assessed by UV spectroscopy using DNA Calculator (Gene-Quant Pharamacia) subjecting a 50-fold dilution of the DNA suspension. The integrity and fidelity of the DNA isolated were checked by electrophoresing uncut DNA, restriction digested DNA (EcoRI, HindIII, PstI, AluI, Sau3AI, HaeIII) and PCR amplified (using primer OPA5) DNA on a 1\% agarose gel.

DNA obtained from the 9 individual coconut palms, 3 each of tall, 3 dwarf and 3 San Ramon were subjected to single-primed polymerase chain reaction (RAPD-PCR) to generate random amplified DNA (RAPD) profiles. A total of 60, oligonucleotide primers (10- mers), labeled OPA1 - OPA20, OPB1 - OPB20 and OPC1- OPC20 were used. These primers were obtained from OPERON Technologies, INC. The sequences of these primers were selected randomly keeping the requirements, $\mathrm{G}+\mathrm{C}$ content between $60-70 \%$ and avoiding self-complementarity at ends. The sequences of the 60 primers are given in Table 2.

The PCR procedure used was based on Williams et al. (1991). The amplification reactions were performed in a thermocycler (Perkin Elmer) in a volume of $25 \mathrm{ml}$ containing $1 \mathrm{x}$ Taq reaction buffer (10 mM Tris. $\mathrm{HCl} \mathrm{pH} 8.3,50 \mathrm{mM}$ Potassium Chloride, $0.001 \%$ gelatin) supplied with the enzyme, $2 \mathrm{mM}$ Magnesium Chloride, $100 \mathrm{mM}$ each of dATP, dCTP, dGTP and dTTP, $0.2 \mathrm{mM}$ of a single 10 mer primer, 50 - $100 \mathrm{ng}$ of genomic DNA and 0.5 units of Taq DNA polymerase. The reaction was allowed to progress in 45 repeating cycles of three phases, denaturing of the genomic DNA ( 1 minutes at $\left.94{ }^{\circ} \mathrm{C}\right)$, annealing of primers $\left(1\right.$ minute at $\left.36^{\circ} \mathrm{C}\right)$ and extension of primers $(2$ minutes at $72{ }^{\circ} \mathrm{C}$ ). The amplification products were analyzed on $1.5-\%$ agarose gels, stained in 0.5 $\mathrm{mg} / \mathrm{ml}$ ethidium bromide for $20 \mathrm{~min}$ and exposing to UV for photographing with Polaroid 667 films. The amplified fragments (bands) were scored by visual inspection of the gel photograph and polymorphisms were scored as presence or absence of homologous bands. To check the consistency of polymorphisms detected each PCR was repeated for three times. 
Table 2. Sequences of the 10-mer primers used to generate RAPD-PCR profiles with DNA from 3 individuals each of coconut varieties, tall, dwarf and San Ramon

\begin{tabular}{|c|c|c|c|c|c|}
\hline Primer & Sequence & Primer & Sequence & Primer & Sequence \\
\hline OPA1 & CAGGCCCTTC & OPB1 & GTTTCGCTCC & OPC1 & TTCGAGCCAG \\
\hline OPA2 & TGCCGAGCTG & OPB2 & TGATCCCTGG & OPC2 & GTGAGGCGTC \\
\hline OPA3 & AGTCAGCCAC & OPB3 & САТСССССТG & OPC3 & GGGGGTCTTT \\
\hline OPA4 & AATCGGGCTG & OPB4 & GGACTGGAGT & OPC4 & CCGCATCTAC \\
\hline OPA5 & AGGGGTCTTG & OPB5 & TGCGCCCTTC & OPC5 & GATGACCGCC \\
\hline OPA6 & GGTCCCTGAC & OPB6 & TGCTCTGCCC & OPC6 & GAACGGACTC \\
\hline OPA7 & GAAACGGGTG & OPB7 & GGTGACGCAG & OPC7 & GTCCCGACGA \\
\hline OPA8 & GTGACGTAGG & OPB8 & GTCCACACGG & OPC8 & TGGACCGGTG \\
\hline OPA9 & GGGTAACGCC & OPB9 & TGGGGGACTC & OPC9 & СTCACCGTCC \\
\hline OPA10 & GTGATCGCAG & OPB10 & CTGCTGGGAC & OPC 10 & TGTCTGGGTG \\
\hline OPA11 & CAATCGCCGT & OPB11 & GTAGACCCGT & OPC11 & AAAGCTGCGG \\
\hline OPA12 & TCGGCGATAG & OPB12 & CCTTGACGCA & OPC12 & TGTCATCCCC \\
\hline OPA13 & CAGCACCCAC & OPB13 & TTCCCCCGCT & OPC13 & AAGCCTCGTC \\
\hline OPA14 & TCTGTGCTGG & OPB14 & TCCGCTCTGG & OPC14 & TGCGTGCTTG \\
\hline OPA15 & TTCCGAACCC & OPB15 & GGAGGGTGTT & OPC15 & GACGGATCAG \\
\hline OPA16 & AGCCAGCGAA & OPB16 & TTTGCCCGGA & OPC16 & САCACTCCAG \\
\hline OPA17 & GACCGCTTGT & OPB17 & AGGGAACGAG & OPC17 & TTCCССССАG \\
\hline OPA18 & AGGTGACCGT & OPB18 & CCACAGCAGT & OPC18 & TGAGTGGGTG \\
\hline OPA19 & CAAACGTCGG & OPB19 & ACCCCCGAAG & OPC19 & GTTGCCAGCC \\
\hline OPA20 & GTTGCGATCC & OPB20 & GGACCCTTAC & OPC20 & ACTTCGCCAC \\
\hline
\end{tabular}

\section{RESULTS}

The method of Weising and Karl (1997) for isolation of DNA from young coconut leaves was satisfactory. Sufficient quantities $(67 \mathrm{mg} / \mathrm{g}$ of leaf tissue) of DNA were yielded with adequate quality for use in the RAPD-PCR. DNA was free of detectable amounts of RNA and accessible to restriction enzymes and Taq polymerase in the PCR.

All the Sixty primers except one (OPC3) yielded RAPD-PCR products with coconut DNA. They generated a total of 448 bands averaging 7 - 8 bands per primer. On repetitive runs, $326(73 \%)$ bands appeared consistently and 138 (42\%) exhibited polymorphism of which 54 distinguished tall, dwarf green and San Ramon, as specific to any one or two of the three genotypes. RAPDs detected by each primer, size of the amplified fragment and coconut forms characterized by each fragment are given in Table 2. Among 54 RAPDs detected 16 and 8 were specific to tall and dwarf respectively and 18 distinguished dwarf and San Ramon from tall, 9 distinguished tall and San Ramon from dwarf and 3 distinguished tall and dwarf green from San Ramon. Figures 1 and 2 illustrate RAPD profiles generated by primers, OPA10 and OPA11 with DNA obtained from 3 individuals each of the coconut forms, tall, dwarf and San Ramon. 


\section{DISCUSSION}

The method for isolation of DNA by Wiesing and Karl (1997) derived from Doyle and Doyle (1990) was observed as appropriate for coconut. The method is simple, cheap and fast, the basic four steps; homogenization, lysis, precipitation and purification require minimum of time and working capacity while giving good yields of DNA. Preclusion of performing expensive, ultracentrifugation-required $\mathrm{CsCl}$ gradients and handling hazardous phenol is noteworthy.

RAPD technique is very useful as it allows testing of large number of primer combinations within a very short period of time. Detection of 54 RAPDs to distinguish coconut forms tall, dwarf and San Ramon by merely testing 60 primers is remarkable in comparison to RFLP and SSRP techniques. The actual number of polymorphisms detected was very much high (>100) but nearly $50 \%$, lacked consistency over repeated runs of PCR.

The three forms of coconut tall, dwarf green and San Ramon are contrasting phenotypes for useful traits, precocity, nuts per palm, nuts per bunch, nut size and shape, copra per nut, copra per palm, tolerance to moisture stress etc., (Liyanage, 1958, Liyanage et al., 1988, Fernando, 1987). Presence of these contrasting characters suggests these three forms as good candidates for analysis of markers for tagging to useful traits. Establishment of segregating populations by self pollination of F1 hybrids, tall $\mathrm{x}$ San Ramon and tall $\mathrm{x}$ dwarf is now in progress at the CRISL and breeders will soon have access to populations for analysis of the segregation of these markers. DNA analysis of bulk segregants to locate QTL by genotyping individuals divided into pools of contrasting phenotypes (Michelmore et al., 1991) is a promising alternative for finding linkage between molecular markers with useful traits in the coconut palm. Screening of more primers in similar manner is appreciable in parallel with the establishment of time consuming detection procedures required for RFLP and SSRP screening.

High level of genetic diversity between tall, dwarf green and San Ramon was also revealed by a molecular assay based on RAPDs (Everard et al., 1998). Tall and San Ramon in particular are very much diverse due to their heterozygous genomes associated with allogamy and their parallel evolution believed to have taken place in African and Asia Pacific regions respectively after dissemination of coconut from the center of origin, probably South East Asia (Harries, 1978, Ashburner, et al., 1997 Rhode, et al., 1995). Dwarf being autogamous evolved at a less pace and resemble more of the form San Ramon. One third (18) of the RAPDs detected in this study separated tall from dwarf green and San Ramon in comparison to one sixth (9) of RAPDs that distinguished dwarf from tall and San Ramon agree with above observations.

\section{ACKNOWLEDGEMENTS}

The author wishes to thank Council of Agricultural Policy, Ministry of Agriculture Sri Lanka for providing financial assistance for this study and Professor Eric Karunayake, Head, Department of Biochemistry, Faculty of Medicine for providing laboratory facilities through SAREC grant for Capacity Building in Biotechnology Professor Eric Department of Agriculture. 

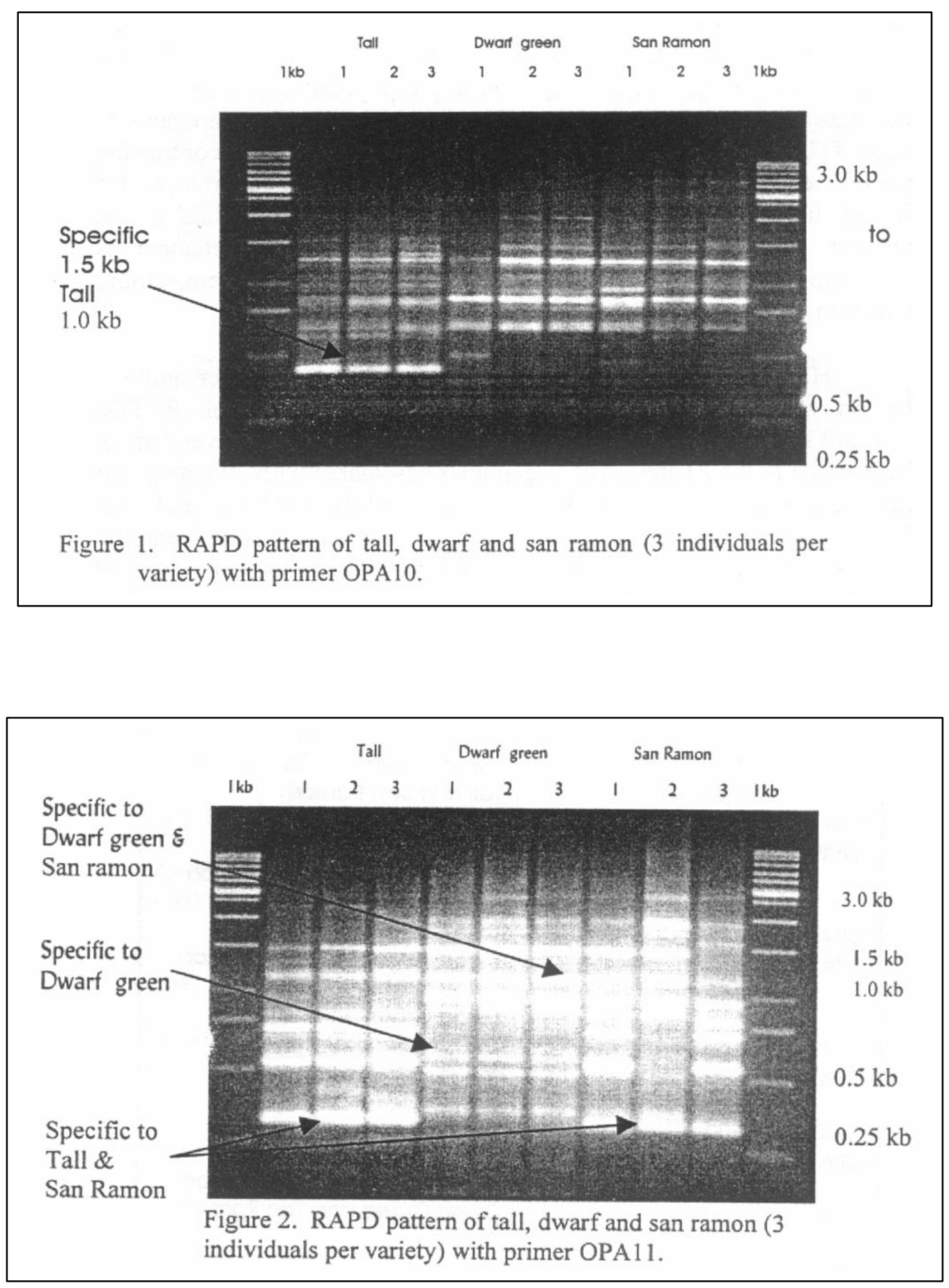
Table 3. RAPDs detected among coconut forms, tall, dwarf green and san ramon

\begin{tabular}{|c|c|c|}
\hline Primer & Fragment size (base pairs) & Sources of DNA positive for amplification \\
\hline OPA 1 & 1,900 & Tall and San Ramon \\
\hline OPA 4 & 725 & Dwarf Green and San Ramon \\
\hline & 300 & Tall and San Ramon \\
\hline OPA 5 & 1,500 & Tall \\
\hline OPA9 & 750 & Tall \\
\hline & 725 & Dwarf Green and San Ramon \\
\hline & 280 & Tall and San Ramon \\
\hline OPA 10 & 475 & Tall \\
\hline OPA 11 & 975 & Dwarf Green and San Ramon \\
\hline & 525 & Dwarf Green \\
\hline & 500 & Dwarf Green \\
\hline & 300 & Tall and San Ramon \\
\hline OPA12 & 800 & Tall \\
\hline & 1,200 & Tall and Dwarf Green \\
\hline OPA14 & 600 & Dwarf Green \\
\hline OPA 15 & 950 & Tall \\
\hline & 450 & Dwarf Green and San Ramon \\
\hline OPA 16 & 250 & Dwarf Green and San Ramon \\
\hline OPA 18 & 800 & Tall \\
\hline OPA 19 & 2,250 & Dwarf Green \\
\hline & 850 & Tall and San Ramon \\
\hline OPA 20 & 1,500 & Dwarf Green and San Ramon \\
\hline & 700 & Tall \\
\hline OPB 1 & 1,000 & Dwarf Green and San Ramon \\
\hline OPB 2 & 550 & Dwarf Green \\
\hline & 500 & Tall and San Ramon \\
\hline OPB 3 & 500 & Dwarf Green and San Ramon \\
\hline OPB 5 & 1,450 & Tall \\
\hline OPB 6 & 500 & Tall and Dwarf Green \\
\hline OPB 8 & 1,000 & Dwarf Green and San Ramon \\
\hline OPB 11 & 500 & \\
\hline & 475 & Dwarf Green and San Ramon \\
\hline & 300 & Tall \\
\hline OPB 13 & 450 & Dwarf Green and San Ramon \\
\hline OPB 15 & 800 & Dwarf Green and San Ramon \\
\hline OPB 16 & 700 & Tall and San Ramon \\
\hline & 500 & Dwarf Green and San Ramon \\
\hline & 100 & Dwarf Green and San Ramon \\
\hline OPB 17 & 1,500 & Tall \\
\hline OPC4 & 1,200 & Tall \\
\hline & 900 & Tall \\
\hline OPC 6 & 1,500 & Dwarf Green \\
\hline & 1,300 & Dwarf Green \\
\hline & 400 & Dwarf Green and San Ramon \\
\hline OPC 7 & 1,000 & Tall and San Ramon \\
\hline OPC10 & 600 & Tall and San Ramon \\
\hline & 300 & Dwarf Green and San Ramon \\
\hline OPC13 & 800 & Tall \\
\hline OPC14 & 800 & Tall \\
\hline & 475 & Dwarf Green \\
\hline & 450 & Tall and Dwarf Green \\
\hline OPC 16 & 750 & Dwarf Green and San Ramon \\
\hline & 700 & Tall \\
\hline OPC 18 & 250 & Dwarf Green and San Ramon \\
\hline
\end{tabular}




\section{REFERENCES}

ASHBURNER, G.R., THOMPSON, W.K. and HALLORAN, G.M. (1997). RAPD analysis of south pacific coconut palm populations. Crop Science 37: 992 - 997

BECKMANN, J.S. and SOLLER, M. (1983). Restriction fragment length polymorphisms in genetic improvement: methodologies, mapping and costs. Theoretical and Applied Genetics. 66; $35-43$

BOTSTEIN, D., WHITE, R.L., SKOLNICK, M.H. and DAVIS, R.W. (1980). Construction of a genetic map in man using restriction fragment length polymorphisms. American Journal of Human Genetics 32: $314-331$

DELLAPORTA, S.L, WOOD, J., and HICKS, J.B. (1983). A plant DNA mini-preparation: version II. Plant Molecular Biology Reporter 1: 19 - 21

DOYLE, J.J. and DOYLE, J.L (1990). Isolation of plant DNA from fresh tissue. Focus 12: 13 - 15

EVERARD, J.M.D.T. (1996a). Use of molecular markers for breeding of the coconut palm, Cocos nucifera. M.Sc. thesis, University of New England, NSW, Australia

EVERARD, J.M.D.T., KATZ, M and GREGG, K. (1996b), Inheritance of RAPD markers in the coconut palm, Cocos nucifera. Tropical Agricultural Research: 8: 124-134

EVERARD, J.M.D.T. and KATZ, M. (1998). Use of RAPDs for estimation of genetic distances between populations of the coconut palm, Cocos nucifera, L. Proceedings of the second Annual Forestry Symposium. University of Sri Jaywardenepura Sri Lanka.

FERNANDO, W.M.U. (1987). San Ramon big with promise. Coconut bulletin 4: 9 Harris. C. (1978). Evolution, dissemination and classification of Cocos nucifera, L.Botanical Review 44:265-320

LIYANAGE,, D.V. (1958). Varieties and forms of the coconut palm grown in Ceylon. Ceylon Coconut Quarterly 9; 1-10

LIYANAGE, D.V., WICKREMARATNE, M.R.T. and JAYASEKARA, C.J. (1988) Coconut breeding in Sri Lanka. Cocos 6: 1 - 26

MICHELMORE, R.W., PARAN, I. and KESSILI, R.V. (1991). Identification of markers linked to disease resistance by bulk segregant analysis: a rapid method to detect markers in specific genomic regions by using segregating populations. Proceedings of the national Academy of Science USA 88: $9828-32$

MULliS, K., FALOON, S., SCHARF, S., SAKAI, R., HORA, G. and EDRICH, H. (1986). Specific enzymatic amplification of DNA in vitro. The polymerase chain reaction. Cold Springs Habour Symposium. Quant Biol. 51: 263-73

MURRAY, M.G. and THOMPSON, W.F. (1980). Rapid isolation of high molecular weight plant DNA. Nucleic Acids Research 8: $4321-4325$

RHODE,, W., KULLAYA, A., RORRIGUEZ, J., and RITTER, E. (1995). Genome analysis of Cocos nucifera L. by PCR amplification of spacer sequences separating a subset of copialike EcoRI repetitive elements. Journal of Genetics and Breeding 49 : 179 - 186 
RHODE, W., SALAMANI, F., ASHBURNER, R. and RANDLES, J.W. (1992). An EcoRI repetitive sequence family of the coconut palm Cocos nucifera L. shows sequence homology to Copia-like elements. Journal of Genetics and Breeding 46; 391 -394

ROGGERS, S.O. and BENDICH, A. J. (1985). Extraction of DNA from milligram amounts of fresh, herbarium and mummified plant tissues. Plant Molecular Biology 5:69-76

SERIKAWA, T, KURAMATO, T, HILBERT, P., MORI, M., YAMADA, J, DAVEY, C.J., LINDPAINTER, K., GANTEN, D., GUENET, J.I., LATHROP, G.N. and BECKERMANN, J.S. (1992). Rat gene mapping using PCR analyzed micro-satellites. Genetics 131: $701-721$

WEISING, K. and KARL, G. (1997). Hybridization-based micro-satellite fingerprinting of plants and fungi in DNA markers; protocols, applications and overviews. G. Caetano-Anolles and P.M. Gresshoff (eds.). pp. $27-53$

WILLIAMS, J.G.K., KUBELIK, A.R., LIVAK, K.J., RAFALSKY, J.A. and TINGEY, S.V. (1991). DNA polymorphisms amplified by arbitrary primers are useful as genetic markers. Nucleic Acids Research 18: 6531

ZABEAU, M and VOSS, P. (1993). Selective restriction fragment length amplification: a general method for DNA fingerprinting. Eur. Pat. App. 92402629.7 (Pub no. 0 534858-A1) 